\title{
Front Matter: Volume 9528
}

, "Front Matter: Volume 9528," Proc. SPIE 9528, Videometrics, Range Imaging, and Applications XIII, 952801 (21 June 2015); doi:

10.1117/12.2197972

SPIE. Event: SPIE Optical Metrology, 2015, Munich, Germany 


\title{
PROCEEDINGS OF SPIE
}

\section{Videometrics, Range Imaging, and Applications XIII}

\author{
Fabio Remondino \\ Mark R. Shortis \\ Editors
}

22-23 June 2015

Munich, Germany

Sponsored by

SPIE

Cooperating Organisations

European Optical Society

German Scientific Laser Society (Wissenschaftliche Gesellschaft

Lasertechnik e.V.)

Published by

SPIE 
The papers included in this volume were part of the technical conference cited on the cover and title page. Papers were selected and subject to review by the editors and conference program committee. Some conference presentations may not be available for publication. The papers published in these proceedings reflect the work and thoughts of the authors and are published herein as submitted. The publisher is not responsible for the validity of the information or for any outcomes resulting from reliance thereon.

Please use the following format to cite material from this book:

Author(s), "Title of Paper," in Videometrics, Range Imaging, and Applications XIII, edited by Fabio Remondino, Mark R. Shortis, Proceedings of SPIE Vol. 9528 (SPIE, Bellingham, WA, 2015) Article CID Number.

ISSN: 0277-786X

ISBN: 9781628416886

Published by

SPIE

P.O. Box 10, Bellingham, Washington 98227-0010 USA

Telephone +1 3606763290 (Pacific Time) · Fax +1 3606471445

SPIE.org

Copyright (@ 2015, Society of Photo-Optical Instrumentation Engineers.

Copying of material in this book for internal or personal use, or for the internal or personal use of specific clients, beyond the fair use provisions granted by the U.S. Copyright Law is authorized by SPIE subject to payment of copying fees. The Transactional Reporting Service base fee for this volume is $\$ 18.00$ per article (or portion thereof), which should be paid directly to the Copyright Clearance Center (CCC), 222 Rosewood Drive, Danvers, MA 01923. Payment may also be made electronically through CCC Online at copyright.com. Other copying for republication, resale, advertising or promotion, or any form of systematic or multiple reproduction of any material in this book is prohibited except with permission in writing from the publisher. The CCC fee code is 0277-786X/15/\$18.00.

Printed in the United States of America.

Publication of record for individual papers is online in the SPIE Digital Library.

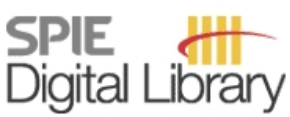

SPIEDigitalLibrary.org

Paper Numbering: Proceedings of SPIE follow an e-First publication model, with papers published first online and then in print. Papers are published as they are submitted and meet publication criteria. A unique citation identifier (CID) number is assigned to each article at the time of the first publication. Utilization of CIDs allows articles to be fully citable as soon as they are published online, and connects the same identifier to all online, print, and electronic versions of the publication. SPIE uses a six-digit CID article numbering system in which:

- The first four digits correspond to the SPIE volume number.

- The last two digits indicate publication order within the volume using a Base 36 numbering

system employing both numerals and letters. These two-number sets start with 00, 01, 02, 03, 04, $05,06,07,08,09,0 A, 0 B \ldots$. 0Z, followed by 10-1Z, 20-2Z, etc.

The CID Number appears on each page of the manuscript. The complete citation is used on the first page, and an abbreviated version on subsequent pages. Numbers in the index correspond to the last two digits of 


\title{
Contents
}

\author{
vii Authors \\ ix Conference Committee \\ xi Introduction
}

\section{SESSION 1 LIGHT FIELD VIDEOMETRY: POINT CLOUD ANALYSIS}

952803 Light-field camera design for high-accuracy depth estimation [9528-2]

952804 Knowledge guided object detection and identification in 3D point clouds [9528-4]

952805 The analysis of selected orientation methods of architectural objects' scans [9528-5]

\section{SESSION 2 STRUCTURED LIGHT AND FRINGE ANALYSIS}

952806 3D measurement with active triangulation for spectacle lens optimization and individualization [9528-10]

952807 Detection of defects in a transparent polymer with high resolution tomography using white light scanning interferometry and noise reduction [9528-11]

952808 3D reconstruction with single image pairs and structured light projection for short-term ultra-high-speed applications [9528-12]

952809 Handheld underwater 3D sensor based on fringe projection technique [9528-13]

9528 OA Profilometry of discontinuous solids by means of co-phased demodulation of projected fringes with RGB encoding [9528-14]

\section{SESSION 3 CALIBRATION AND ACCURACY}

9528 OB Development of orientation method with constraint conditions using vector data [9528-6]

9528 OC Development, comparison, and evaluation of software for radial distortion elimination [9528-7]

9528 OD Relevance of ellipse eccentricity for camera calibration [9528-8]

9528 OE Self-calibration of a structured light based scanner for use in archeological applications [9528-9] 
9528 OG Assessment of the accuracy of 3D models obtained with DSLR camera and Kinect v2 [9528-16]

$9528 \mathrm{OH} \quad$ Improving automated 3D reconstruction methods via vision metrology [9528-17]

9528 Ol Determining the coordinates of lamps in an illumination dome [9528-18]

\section{SESSION 5 IMAGE SEQUENCES AND TRACKING: UAV APPLICATIONS}

9528 0J Tracking of object deformations in color and depth video: deformation models and applications (Invited Paper) [9528-19]

9528 OK Comparison between single and multi-camera view videogrammetry for estimating 6DOF of a rigid body [9528-20]

$9528 \mathrm{OL}$ Fast instantaneous center of rotation estimation algorithm for a skied-steered robot [9528-21]

9528 OM Investigating influence of UAV flight patterns in multi-stereo view DSM accuracy [9528-23]

\section{SESSION $6 \quad$ IMAGE MATCHING AND SURFACE MODELS}

$95280 \mathrm{~N} \quad$ Multi-image semi-global matching in object space [9528-24]

952800 3D city models completion by fusing lidar and image data [9528-25]

9528 OP DTM generation from STC-SIMBIO-SYS images [9528-26]

$95280 Q \quad$ Stereo matching based on census transformation of image gradients [9528-27]

\section{SESSION 7 RANGE IMAGING MODELLING AND ANALYSIS}

9528 OR Single-plane versus three-plane methods for relative range error evaluation of mediumrange 3D imaging systems [9528-28]

9528 OS Extracting the MESA SR4000 calibrations [9528-29]

9528 OU Enhancing swimming pool safety by the use of range-imaging cameras [9528-31]

9528 OV Evaluating the capability of time-of-flight cameras for accurately imaging a cyclically loaded beam [9528-32] 
9528 0X Precise deformation measurement of prestressed concrete beam during a strain test using the combination of intersection photogrammetry and micro-network measurement [9528-34]

9528 OY A simple and flexible calibration method of non-overlapping camera rig [9528-35]

952810 The phase correlation algorithm for stabilization of capillary blood flow video frames [9528-37]

952812 Efficient estimation of orthophoto images using visibility restriction [9528-39]

952813 Action cameras and low-cost aerial vehicles in archaeology [9528-40]

952814 Miniaturized 3D microscope imaging system [9528-41]

952815 Improving depth estimation from a plenoptic camera by patterned illumination [9528-42]

952816 Frequency-spatial cues based sea-surface salient target detection from UAV image [9528-43] 
Proc. of SPIE Vol. $9528952801-6$

Downloaded From: https://www.spiedigitallibrary.org/conference-proceedings-of-spie on 26 Apr 2023 Terms of Use: https://www.spiedigitallibrary.org/terms-of-use 
Schmidt, Ingo, 09

Seitz, Peter C., 06

Serio, B., 07

Servin, M., OA

Shang, Yang, OY

Simioni, E., OP

Skarlatos, Dimitrios P., OM

Stentoumis, C., OO, OQ

Steward, Jeremy, OV

Streeter, Lee, OS

Štroner, Martin, OX

Styles, lain B., 15

Sun, Xiaoliang, 16

Sung, Hsin-Yueh, 14

Tiemann, Markus, 06

Tietz, B., 04, OD

Toschi, Isabella, $\mathrm{OH}$

Turola, Massimo, 15

Uhring, W., 07

Urban, Rudolf, OX

Vamvakousis, Vasilis, OM

Vlachos, Marinos, OM

Volkov, Mikhail V., 10

Wang, Yen-Chang, 14

Wanner, S., 03

Yu, Qifeng, OY, 16

Zawieska, Dorota, 05

Zhang, Xiaohu, OY 


\title{
Conference Committee
}

\author{
Symposium Chairs
}

Wolfgang Osten, Institut für Technische Optik (Germany)

Gunther Notni, Fraunhofer-Institut für Angewandte Optik und

Feinmechanik (Germany)

Andrew John Moore, Heriot-Watt University (United Kingdom)

Conference Chairs

Fabio Remondino, Fondazione Bruno Kessler (Italy)

Mark R. Shortis, RMIT University (Australia)

Conference Programme Committee

Jean-Angelo Beraldin, National Research Council Canada (Canada)

Jan Boehm, University College London (United Kingdom)

Werner Boesemann, AICON 3D Systems GmbH (Germany)

Simon Buckley, Centre for Integrated Petroleum Research (Norway)

Takashi Fuse, The University of Tokyo (Japan)

Gabriele Guidi, Politecnico di Milano (Italy)

Derek D. Lichti, University of Calgary (Canada)

Thomas Luhmann, Jade Hochschule (Germany)

Hans-Gerd Maas, Technische Universität Dresden (Germany)

Jon P. Mills, Newcastle University (United Kingdom)

Norbert Pfeifer, Technische Universität Wien (Austria)

Stuart Robson, University College London (United Kingdom)

David Stoppa, Fondazione Bruno Kessler (Italy)

Session Chairs

$1 \quad$ Light Field Videometry: Point Cloud Analysis

Fabio Remondino, Fondazione Bruno Kessler (Italy)

2 Structured Light and Fringe Analysis

Takashi Fuse, The University of Tokyo (Japan)

3 Calibration and Accuracy

Mark R. Shortis, RMIT University (Australia)

4 Metrology Applications

Mark R. Shortis, RMIT University (Australia) 
5 Image Sequences and Tracking: UAV Applications

Thomas Luhmann, Jade Hochschule (Germany)

6 Image Matching and Surface Models

Stuart Robson, University College London (United Kingdom)

$7 \quad$ Range Imaging Modelling and Analysis

Fabio Remondino, Fondazione Bruno Kessler (Italy) 


\section{Introduction}

The Videometrics, Range Imaging, and Applications XIII conference is the fifteenth in a series started in 1991 by Sabry El-Hakim. Under the auspices of the International Society for Optics and Photonics (SPIE) from the beginning, the first conference on Industrial Vision Metrology was held in Winnipeg, Canada. Based on the success of this first venture into an emerging discipline, the conference was renamed Videometrics and held in conjunction with the SPIE Photonics East group of conferences in Boston and Philadelphia during 1992-1995. Videometrics was then re-located to become part of SPIE Photonics West, held annually in California. The conferences were held once in San Diego in 1997, then twice in San Jose in 1999 and 2001 (given the longer title of 'Videometric and Optical Methods for 3D Shape Measurement'), then moved to Santa Clara in 2003 and moved back to San Jose in 2005 and 2007. More recently Videometrics became part of Optics + Photonics program track on Image and Signal Processing within the Optical Engineering and Applications conferences in San Diego in 2009. The conference was renamed to 'Videometrics, Range Imaging, and Applications' to reflect the changes in contemporary practice.

Throughout all of this period the attendance from North America was slowly declining, and the participation from Europe and Asia had strengthened, despite the impact of the global financial downturn. Therefore in 2011 it was decided to move the Videometrics series to Munich, Germany, to be part of the SPIE Europe conference on Optical Metrology, co-located with the World of Photonics conference and exhibition. The general theme of Optical Metrology resonates very well with Videometrics and the majority of authors and presenters from Europe confirmed the correct decision to relocate the conference.

Irrespective of the location, for more than two decades the Videometrics conference series has been providing a unique forum for optical metrology, computer vision, image processing and photogrammetry researchers and practitioners to present the latest advances in precise 3D measurement and modeling from imaging and range sensors. This conference was originally focused on the metric performance of image sensors and algorithms to produce the most accurate and reliable geometric measurements and models. Topics such as sensor calibration, performance evaluation and accurate object reconstruction were predominant. This has now been expanded to encompass all phases of 3D optical imaging, range imaging and modeling of real scenes, including automation of data collection and processing, improving the visual quality and realism, visualization, animation and data management for real-time manipulation. This is in response to the sustained increase in interest in 3D imaging and modeling technology, and the increased demand of these models in applications such as rapid product development, virtual museums, documentation of monuments and architecture for cultural heritage, marketing 
and tourism, human body modeling, medicine, and exploration of remote and hazardous sites, to name just a few.

In 2015 Videometrics, Range Imaging, and Applications XIII demonstrates the continuing broad interest in 3D optical imaging, with sessions encompassing all aspects of the field, from performance evaluation to 3D modeling and applications. The three invited speakers reinforce this span of interest: Professor Bernd Jaehne (Heidelberg Universität, Germany) presenting on light field-based videometry; Professor Reinhard Koch (German Christian-Albrechts-Universität zu Kiel, Germany) presenting on real time tracking of deforming surfaces with color+depth cameras; and Professor Stuart Robson (University College London, United Kingdom) presenting on optical metrology with low cost camera systems for advanced manufacturing. Whilst Videometrics embraces new technologies such as enhancing time of flight range imaging and developing new techniques such as in the area of fusion of range and image data, the classical problems of precise measurement and robust tracking are still well represented. The proceedings of Videometrics always contain something of interest for all practitioners involved in the 3D optical imaging field.

The Chairs recognise and acknowledge with gratitude the efforts of the Conference Committee members, the authors, presenters and audience, and especially the invited speakers, in maintaining the high level of interest in the Videometrics series of events. We acknowledge and appreciate the contribution to the success of the conference from everyone involved in Videometrics.

Fabio Remondino Mark R. Shortis 